\title{
GEOLOGICAL STRUCTURE OF THE NORTHERN EASTERN BLACK SEA FROM REGIONAL SEISMIC REFLECTION DATA, INCLUDING THE DOBRE-2 CDP PROFILE
}

by

Sydorenko, G. ${ }^{1}$, Stephenson, R. ${ }^{2}$, Yegorova, T. ${ }^{3}$, Starostenko, V. ${ }^{3}$, Tolkunov, A. ${ }^{1}$, Janik, T. ${ }^{4}$, Majdanski, M. ${ }^{4}$, Voitsitskiy, Z. ${ }^{1}$, Rusakov, O. ${ }^{3} \&$ Omelchenko, V. ${ }^{3}$

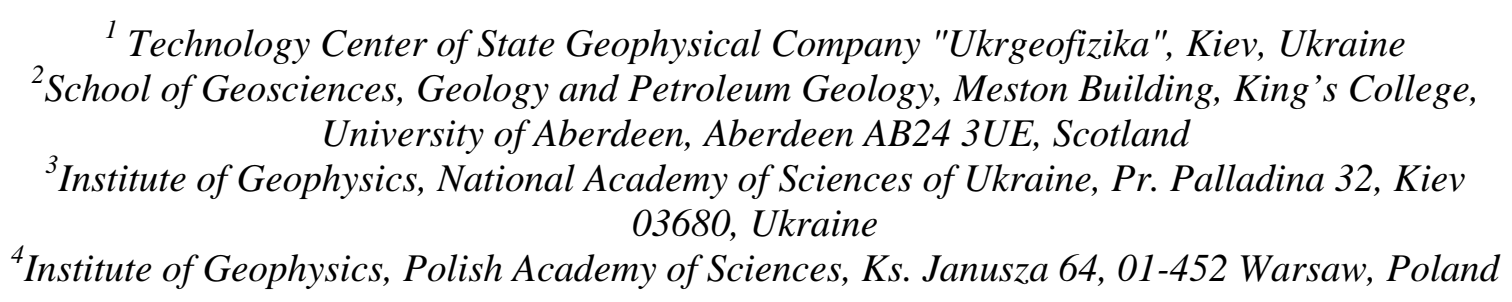


Abstract

The margin of the northeastern Black Sea is formed by the Crimea and Kerch peninsulas separating it from the Azov Sea to the north. The age and architecture of the sedimentary successions in this area are described from exploration reflection seismic profiling acquired in the area as well as the "one-off” regional DOBRE-2 CDP profile acquired in 2007. The sediments range in age from Mesozoic to Quaternary and can be divided into five "seismostratigraphic" complexes linked to the tectono-sedimentological evolution of the area. The present regional basin architecture consists of a series of basement structural highs separating a series of sedimentary depocentres and is mainly a consequence of the compressional tectonic regime affecting the area since the Eocene and which has focused shortening deformation and uplift along the axis of the Crimea-Caucasus inversion zone on the Kerch Peninsula and Kerch Shelf of the Black Sea. Two major sedimentary basins that mainly formed during this time the Sorokin Trough in the Black Sea and the Indolo-Kuban Trough to the north of the Kerch Peninsula in the Azov Sea - formed as marginal troughs to the main inversion zone.

Keywords: Crimean Mountains, Greater Caucasus Mountains, East Black Sea Basin, Azov Sea, seismic reflection profiles, inversion tectonics, sedimentary basin formation

This paper focuses on the subsurface geology of the northeastern part of the Black Sea (Fig. 1), in particular its regional architecture of basin depocentres and basement ridges. The margin of the northeastern Black Sea is formed by the Crimea and Kerch peninsulas separating it from the Azov Sea to the north.

The Black Sea as a whole consists of a roughly east-west orientated depression, mainly formed in the Cretaceous in the hinterland of the Pontide magmatic arc due to subduction of Neotethyan lithosphere below the southern Eurasian continental margin (Dercourt et al. 1993; Okay et al. 1994; Robinson \& Kerusov 1997; Nikishin et al. 2003; Stephenson \& Schellart 2010). At present the Black Sea is underlain by a flat, approximately $2 \mathrm{~km}$ deep, abyssal plain that obscures two separate large depressions called the West and East Black Sea (WBS and EBS) basins. These overlie crustal basement of uncertain composition and tectonic age and structure and are filled with up to $14 \mathrm{~km}$ of Mesozoic and Cenozoic sediments (Graham et al. 2013; Nikishin et al. 2015a,b). The WBS and EBS basins are separated by a Mid-Black Sea 
Ridge (MBSR), the northernmost component of which is the Andrusov Ridge, as seen in $80 \quad$ Figure 1.

81

82

83

84

85

86

87

88

89

90

91

92

93

94

95

96

97

98

99

100

101

102

103

104

105

106

107

108

109

110

111 The wide-angle refraction and reflection (WARR) profile DOBRE-2 (Starostenko et al. this

112 volume), utilizing on- and offshore recordings and energy sources, was acquired in 2007 by

The Crimean Mountains, on the southern margin of the Crimea Peninsula, is the main onshore expression of the Crimea-Greater Caucasus orogenic belt in the northeastern Black Sea study area, running eastwards into southern Russia and Georgia. The contiguous offshore part of the orogen in the present study area is referred to here as the Crimea-Caucasus inversion zone (Fig. 1). It retains the memory of Mesozoic-Early Palaeogene extension as well as Eocene to Miocene contraction of the lithosphere, effected mainly by thrusting. The greater regional tectonic setting of the study area is described in accompanying papers in this volume (e.g. Gobarenko et al. this volume; Starostenko et al. this volume).

The regional geological structure of the Black Sea has been under investigation since the 1980s when regional seismic lines for the entire area were published (Tugolesov et al. 1985; Finetti et al. 1988; Belousov \& Volvovsky 1989). More recent seismic data acquired in the EBS and adjacent areas have been published by Robinson et al. (1996), Afanasenkov et al. (2007), Shillington et al. (2008), Rangin et al. (2002), Khriachtchevskaia et al. (2010), Stovba et al. (2009), Nikishin et al. (2010), Mityukov et al. (2012), Almendinger et al. (2011), TPAO/BP Eastern Black Sea Project Study Group (1997), Gozhyk et al. (2010) and Graham et al. (2013). A set of long regional deep seismic lines acquired in 2011 in the framework of the international project "Geology Without Limits" allowed a new map of acoustic basement for the whole Black Sea to be proposed (e.g. Nikishin et al. 2015a,b).

Marine seismic reflection surveys within the present study area were first done before the end of the last century. Among the first regional 2D seismic surveys in the area were the Western Geophysical (1994) and Polar Trade Research Associates (2005) surveys (Fig. 1; right-hand panel). A successful exploratory well was drilled on the Subbotina anticline structure, followed up by additional wells (Fig. 1; right-hand panel) and the more detailed 3D CDP Titul survey undertaken by Ukrgeofizika in 2008 (Fig. 1; right-hand panel). The focus of the present study is on the area lying to the south of Kerch Peninsula within the Kerch Shelf, Sorokin Trough, North Black Sea High, Shatsky Ridge and East Black Sea Basin (Fig. 1). 
113 Ukrainian organizations and international partners across the Azov Sea, eastern Kerch

114 Peninsula and the eastern Black Sea. The coincident DOBRE-2 regional CDP line, crossing

115 the Azov Sea, Kerch Peninsula, and the north-eastern part of the Black Sea (Fig. 1), was

116 acquired by Ukrgeofizika (the Ukrainian national geophysical company) also in 2007 . The

117 geological interpretation of the DOBRE-2 CDP data are presented here, carried out in the

118 context of other seismic reflection profiling in the area and its ties to wells. The results

119 illuminate the structural relationships and ages of extensional and subsequent basin inversion

120 tectonic events as well as the 2D geometry of basement displacement associated with post-

121 Eocene inversion in this key segment of the Crimea-Caucasus deformation belt. Further, the

122 complete DOBRE-2 CDP profile (including its Kerch Peninsula and Azov Ridge segments) is

123 briefly examined in view of the presented results to examine the structural style of the

124 Crimean-Caucasus inversion zone as a whole and its associated sedimentary basins.

\section{Geological setting}

128 Rifting is the major (first-order) geodynamic process responsible for the tectonic evolution of

129 the Black Sea basins, related to closure of the Tethys and Neotethys oceans (Zonenshain \& Le

130 Pichon 1986; Letouzey et al. 1977; Görür 1988; Okay et al. 1994; Robinson et al. 1996;

131 Nikishin et al. 2003; Stephenson \& Schellart 2010). However, the timing of opening of the

132 Black Sea basins (i.e., the age of the oldest sediments) remains controversial. A Cretaceous

133 age was inferred from onshore geological observations by Adamia et al. (1974), Letouzey et

134 al. (1977), Görür (1988) and Nikishin et al. (2003). An Early Cretaceous to Palaeocene

135 opening was deduced by Finetti et al. (1988) from extensive seismic reflection data,

136 corresponding with the concepts of Zonenshain \& Le Pichon (1986) and Robinson et al.

137 (1996). Stephenson \& Schellart (2010) suggested that there was a single stage opening of

138 Black Sea as a back-arc basin resulting from asymmetric slab roll-back. Nikishin et al.

139 (2015b) concluded that continental rifting manifested itself from the Late Barremian to the

140 Albian, while the age of opening of the deepest basins with (sub-) oceanic crust was from

141 Cenomanian until mid-Santonian.

143 At present the Black Sea is undergoing compressional deformation that has been active since

144 the Eocene (Saintot et al. 2006b; Khriachtchevskaia et al. 2010; Stovba \& Khriachtchevskaia

145 2011), or possibly Palaeocene (Sheremet et al. this volume), related to convergence of the

146 Eurasian and Afro-Arabian plates, seen, for example, as underthrusting of the Black Sea crust 
147 below the crust of the Scythian platform of the Crimean and Kerch-Taman peninsulas

148 (Gobarenko et al. this volume).

150 The Crimean Mountains can be considered as the western prolongation of the Greater

151 Caucasus orogen. It is widely associated with strongly deformed Upper Jurassic-Lower

152 Cretaceous sedimentary strata, which are overlain by thin Cenozoic sediments (Kruglov \&

153 Tsypko 1988). Popadyuk (2013) reported an Albian age for these strata (which they assigned

154 to the Tauric Group), which compares with recent nannofossil dating of them in the eastern

155 Crimean Mountains reported by Sheremet et al. (this volume). These flysch series are

156 characterized by detrital deposits, turbidites and large olistostromes containing blocks of

157 different sizes and ages. The presence of substantial volcanic ash reported by Sheremet et al.

158 (this volume) suggests their deposition at the same time as Early Cretaceous volcanic activity

159 in the area, which is supported the radiometric dating of Meijers et al. (2010) in eastern

160 Crimea and Nikishin et al. (2013) in western Crimea.

162 The DOBRE-2 CDP profile is located in the transition from the subdued offshore part of

163 Crimean orogenic belt south of the eastern Crimea Peninsula to the EBS Basin, crossing

164 numerous thrust and thrust-related folds and syn-compressional sedimentary depocentres.

165 These include the Sorokin Trough and associated positive structures, such as the Tetyaev

166 Uplift, the North Black Sea High and the Shatsky and Andrusov ridges (Fig. 1). The last two

167 form the northeastern and southwestern margins respectively of the parallel EBS Basin, which

168 is filled with Cretaceous and younger sediments as thick as $14 \mathrm{~km}$ that overlie a high-velocity

169 crystalline crustal layer with Moho lying at a depth of 20-24 km (Starostenko et al. 2004; Scott

170 et al. 2009; Shillington et al. 2009; Yegorova et al. 2010, 2013). The Andrusov Ridge is part

171 of the Mid-Black Sea Ridge, which is underlain by continental crust as thick as $28-29 \mathrm{~km}$ (e.g.

172 Shillington et al. 2009; Yegorova et al. 2010).

173

174 The study area is known to host significant oil and gas potential (e.g. Pobedash 2006; Stovba

175 et al. 2009). The most important discoveries in this regard are related to compressional

176 structures in an area referred to as the Kerch-Taman Trough immediately south of the Kerch

177 Strait (cf. Nikishin et al. this volume), the inlet to the Azov Sea from the Black Sea between

178 the Kerch and Taman peninsulas. 

profiling

Regional investigations of the Ukrainian sector of the northeastern Black Sea have been carried out using a vast set of regional seismic reflection profiles $(\sim 10000 \mathrm{~km})$, including those acquired by Western Geophysical in 1994 and by Polar Trade Research Associates in 2005. These data, augmented by Ukrgeofizika data acquired in 2007 (DOBRE-2) and 2008 (Titul), form the basis of the present paper. The location and distribution of these datasets are shown in Fig. 1 (right-hand panel) with the specific profiles reproduced in this paper highlighted accordingly. The main acquisition and processing parameters for the utilized seismic surveys are listed in Table 1.

Stratigraphic correlation

Onshore seismic reflection surveys for hydrocarbon exploration were carried out on the Kerch Peninsula since the middle of the $20^{\text {th }}$ century and led to the discovery of a number of oil, gas and gas condensate deposits in sedimentary strata of mainly Cenozoic age (cf. Fig. 1). The seismic stratigraphy established onshore by Ukrgeofizika (and other Ukrainian organisations such as Odesmorgeologia) was extrapolated and further developed in the offshore region beginning with the 1994 Western Geophysical survey. Figure 2 shows the main seismic horizons, some of which correspond to local and regional unconformities, that are readily identified according to a lengthy and vast experience of seismic interpretation in the study area.

Well-ties with seismic offshore are scarce in the study area except around the Subbotina discovery mentioned above. Figure 3 exemplifies the geological interpreted seismic stratigraphy of the area for one profile calibrated by the wells drilled on the Subbotina structure. For the present study specifically, which includes the unique DOBRE-2 regional

210 CDP profile, correlation of regional reflections with stratigraphic horizons was reassessed in 211 two stages. The first of these was based on calibration with the Subbotina wells as seen in

212 Figure 3, with Subbotina-403, the discovery well and also the deepest, terminating in the 213 Lower Eocene succession. (More details of these wells and the seismic in the immediate area 
214 of the Subbotina field can be found in Stovba et al. [2009], Gozhyk et al. [2010] and

215 Starostenko et al. [2011]). The second stage involved extrapolating the DOBRE-2 profile from

216 the (onshore) Kerch Peninsula, where the subsurface seismic stratigraphy has been well-

217 established, to the deeper part of the EBS Basin. What follows in this section is, first, a general

218 description of the established seismic stratigraphy of the study area with examples from the

219 utilized exploration datasets (Figs. 3-5; profiles located in Fig. 1) and then the Black Sea

220 segment of the DOBRE-2 regional CDP profile with a geological interpretation in this context

221 (Fig. 6).

222

223

Regional seismo-stratigraphic complexes

224

225 The seismic stratigraphy of the northern EBS area has conventionally been subdivided into 226 seven main "seismo-stratigraphic complexes" (e.g. Gozhyk at al. (2011). In the present paper, 227 a more robust subdivision of only five such complexes is considered: a Mesozoic complex, a 228 Palaeocene-Eocene complex; the Maykopian succession of Oligocene and Early Miocene age; 229 a Middle and Upper Miocene complex and a Pliocene-Quaternary succession. These are based 230 primarly on the work of Pobedash (2008), which utilised the stratigraphy results of the

231 Subbonina-403 well (cf. Fig. 1), as well as those of Popadyuk (2009).

232

233 The Mesozoic seismo-stratigraphic complex is characterized by low-grade (weak) reflections 234 on the seismic sections in this area. The top of this complex is horizon IIIm (Fig. 2), which is 235 expressed clearly on the Andrusov and Shatsky ridges and in the intervening EBS Basin (e.g. 236 Fig. 6). It is generally an erosional surface on the top of Mesozoic strata. It is difficult to 237 identify within the Sorokin Trough (e.g. Fig. 4) probably because of its high dip angle 238 conformable with overlying Cenozoic sediments. The relatively chaotic nature of reflectivity 239 within the the Mesozoic strata underlying IIIm (e.g. Figs. 4, 5) is likely related to faulting of 240 probable Cretaceous age associated, for example, with Black Sea rifting. The age of 241 underlying Mesozoic strata, below horizon IIIm, varies from place to place, which complicates 242 the seismic stratification and the erosional gap may be considerable.

244 The Palaeocene-Eocene seismo-stratigraphic complex lies between horizons IIIm and IIa. The

245 Subbotina-403 well penetrated the Eocene succession, which consist mainly of marl with 246 interlayers of clay. This complex displays good dynamic reflections in the time sections. In 247 general, the sediments of this complex occur in troughs and depressions of the northern EBS 
area (e.g. Figs. 5, 6) and it may be partly (e.g. Fig. 3) or wholly missing in places such as across the North Black Sea High (Fig. 4). The complex may be present within the Sorokin Trough but the overlying horizon IIa is not clearly identifiable, for example, on seismic line 161-94 (Fig. 4).

The Maykopian seismo-stratigraphic complex (Oligocene-Lower Miocene), lying between seismic horizons Ia and IIa, is characterized by reflections of variable amplitude. According to the Subbotina-403 well lithostratigraphy, the Lower Miocene succession is represented by clay with siltstone interlayers, with some sandtone layers near its base, and the Oligocene succession is represented mainly by clay and, towards its base, by clay with interlayered siltstones and sandstones. Hydrocarbons are found in some of sand units. In the Sorokin Trough the Maykopian complex is tectonically folded (e.g. Figs. 4, 6). Within the EBS Basin it conformably repeats the structural forms of the Mesozoic complex with gradual flattening (Figs. 4, 5) and covers the positive structures within the basin (e.g. North Black Sea High, Shatsky and Andrusov ridges; Figs. 4-6) as well as the troughs as the basin subsides as a whole. It is noted that the thickness of the Maykopian complex in the present interpretation (e.g. Fig. 6) is much thicker over the EBS Basin and Andrusov Ridge than is other recent interpretations (e.g. Stovba et al. 2013; Nikishin et al. 2015a,b; Nikishin et al., this volume). This is because the present interpretation was made prior to release of information from the Sinop-1 well drilled on the Andrusov Ridge in Turkish territory (located in Fig. 1) and, accordingly, was based on extrapolation from the Subbotina wells and other correlation points on and near the Ukrainian Black Sea margin.

\section{The Middle-Upper Miocene seismo-stratigraphic complex lies between seismic horizons Ip} and Ia. The latter, basal, horizon has no obvious signs of unconformity but can be associated with a change in how the amplitude dynamics of the seismic wave field is expressed. Within the Subbotina field the Upper Miocene is represended by clay and the the Middle Miocene by clay with marl interbeds of the Tortonian age. Horizon Ip, marking the top of this complex and the end of the Miocene, is an erosional surface (e.g. Figs. 3, 4).

\section{The Pliocene-Quaternary seismo-stratigraphic complex is composed mainly of terrigenous} sediments. It is supposed that the component clastic materials were transported into the basin by the predecessors of the modern Don, Kuban and other rivers. 
The Black Sea segment of the DOBRE-2 CDP profile shown in Figure 6 provides a regional scale image of the geological structure of the main study area. A brief description follows, highlighting the main diagnostic features of the geological structures - depocentres and structural highs - traversed along it. Much of the detailed structural complexity associated with the Cenozoic compressional tectonic stage, including mud diapirism, is obscured at the scale of interpretation and, in turn, much of the Mesozoic extensional tectonic structures are obscured by the later shortening processes. It is beyond the scope of the current paper to go into details that may be relevant to specific hydrocarbon exploration targets, including lithologies that could represent source rocks, traps or reservoirs and associated structures. The main focus is on the regional-scale relationships between structural highs and depocentres and the relative ages of each.

The northernmost part of the DOBRE-2 CDP profile (Fig. 6) images the submerged (below sea level) southernmost part of the Crimean-Caucasus foldbelt, which is complicated by fault tectonics and volcanic activity (e.g. Meijers et al. 2010). Jurassic- Lower Cretaceous complexes can be identified in the seismic section, partly on the basis of correlation with subsurface data from the southernmost part of Kerch Peninsula and partly on gravity coring in the Black Sea (e.g. Tsiokha et al. 2008). Immediately south of the inversion zone, the profile crosses what is referred to as the Kerch Shelf, which, being composed of strongly blockfaulted Jurassic and Cretaceous sedimentary strata, is geologically very similar to the inversion zone itself. The Jurassic and Cretaceous successions are as thick as at least $2500 \mathrm{~m}$ and more than $700 \mathrm{~m}$, respectively, and show the presence of an anticlinal structure that has been eroded. The southern flank of the anticline is separated from its axis by a reverse fault. The

308 Upper Jurassic sediments here are deformed by a series of low-amplitude faults in small folds.

309 Cretaceous, Palaeocene-Eocene and Maykopian strata are missing because of erosion.

310 Erosional surfaces are indeed typically found within the Oligocene-Miocene succession of the

311 Kerch Shelf. The strata on the shelf, along a system of faults affecting basement and the

312 Mesozoic succession, are dipping southwards towards the Sorokin Trough. The transition from

313 the shelf to the Sorokin Trough occurs along a fault with some $2500 \mathrm{~m}$ displacement. The

314 interpretation shown indicates that there is normal displacement on this fault (e.g. offset of

315 what is interpreted as horizon IIIm), in which case it was formed initially during Black Sea 
316 rifting and has been inverted during the later Cenozoic compressional phase of tectonics

317 although this cannot be documented at the scale of the image.

319 The Sorokin Trough is filled mainly with Maykopian sediments (Oligocene-Lower Miocene)

320 and, in this respect, differs significantly in structure and seismic appearance to the Kerch Shelf

321 to the north and and the North Black Sea High to the south. The Sorokin Trough formed at the

322 beginning of the Oligocene and is filled with up to $5250 \mathrm{~m}$ of clay-rich Maykopian sediments,

323 overlain by Middle Miocene and younger strata, these being dominated by alluvial fan

324 deposits. Seismic horizon IIa, which marks the base of the Maykopian complex, is observed as

325 deep as $6.5 \mathrm{~s}$ ( $\sim 8300 \mathrm{~m}$ depth) at the deepest point of the Sorokin Trough but cannot be

326 identified with confidence on the northen flank of the trough, which is structurally very

327 complex and is also affected locally by mud diapirism. Maykopian strata in the north-western

328 part of the trough form rather high-amplitude thrust-related folds that display a clear southern

329 vergence on the southern margin of the Trough along the DOBRE-2 profile.

330

331 On its southwestern margin the Sorokin Trough adjoins the North Black Sea High (and

332 contiguous Shatsky Ridge). The southern flank of the North Black Sea High, in turn, adjoins

333 the EBS Basin through a zone in which the Cretaceous and older strata are highly faulted. A

334 notable feature of the North Black Sea High (also seen well in Fig. 4) is the antiformal

335 structure composed of Mesozoic rocks as thick as $1500 \mathrm{~m}$ in its core. Numerous normal and

336 reverse faults affect the Mesozoic strata on the southern flank of the North Black Sea High-

337 Shatsky Ridge positive structure but faulting does not define the Palaeocene-Eocene (and, in

338 part, the Oligocene) depocentre of the adjacent EBS Basin. Stratal horizons of the EBS Basin

339 onlap the interpreted IIIm horizon (top Mesozoic) on both its flanks, less steeply on the

340 northern margin with the Shatsky Ridge-North Black Sea High than the southern margin with

341 the Andrusov Ridge. According to the interpretation seen in Figure 6, the maximum depth to

342 the base Cretaceous (horizon IV) in the EBS Basin is located at a depth of $\sim 11650 \mathrm{~m}$.

343

344 The DOBRE-2 CDP profile terminates on the Andrusov Ridge, which is part of the Mid-Black

345 Sea Ridge that separates the WBS and EBS basins. The positive structure of Andrusov Ridge

346 is distinguished on the basis of seismic reflection horizon IIIm, which defines a wide arch.

347 Cretaceous as well as Upper and Middle Jurassic units have been inferred in the Mesozoic

348 strata on Andrusov Ridge according to patterns seen in the reflection section (e.g. stratal

349 terminations, erosional truncations and other features; Tsiokha et al. 2008). 


\section{The DOBRE-2 CDP profile as a whole}

352

353

354

355

356

357

358

359

360

361

362

363

364

365

366

367

368

369

370

371

372

373

374

375

376

377

378

379

380

381

382

383

The main focus of this paper is the regional basin architecture of the northeastern EBS, coincident with the southern margin of the Crimea-Caucasus inversion zone and south of it, where it has been imaged by the Black Sea segment of the DOBRE-2 regional CDP profile. It is nevertheless instructive to consider this in the context of the basin architecture imaged by the rest of the DOBRE-2 CDP profile and the coincident DOBRE-2 WARR profile.

Figure 7 shows in its upper panel a compressed version of the DOBRE-2 CDP profile (the segment displayed in Figure 6 as well as segments acquired onshore the Kerch Peninsula and offshore in the Azov Sea). The main features to be seen in the basin architecture below the Kerch Peninsula and Azov Sea segments include a marked asymmetry of the CrimeaCaucasus inversion zone, with a much thicker Maykopian complex on the northern margin of the inversion zone than on the south. This in turn overlies a succession interpreted to be Cretaceous that is much thicker than on the southern margin of the inversion zone. This major sedimentary depocentre is called the Indolo-Kuban Trough and lies essentially conformably on Jurassic basement that shallows rapidly to the north. Further north is a series of partially inverted half grabens containing Mesozoic and Palaeogene strata called the North Azov Trough. The zone of shallower basement between the Indolo-Kuban Trough is the Middle Azov Uplift, where basement is shallowing, and the Azov Ridge, where the basement surface is more or less flat.

The lower panel of Figure 7 displays the WARR velocity model of Starostenko et al. (this volume) converted to two-way travel-time and displayed at the same scale as the CDP profile above it. In general in the WARR model velocities in the range $1.8-4.5 \mathrm{~km} / \mathrm{s}$ can be considered to represent relatively undisturbed sedimentary rocks while velocities above this but less than $\sim 5.8 \mathrm{~km} / \mathrm{s}$ may also represent sedimentary strata though deeply buried and highly indurated, including carbonates such as those representing the Upper Jurassic succession in study area (e.g. Nikishin et al. 2015a). Higher velocities almost certainly represent crystalline basement (cf. Starostenko et al. this volume). No exact correspondence of velocity-seismic boundaries is expected, of course, since the CDP method delineates clearly horizontal or gently inclined reflectors while the WARR method can recognize near vertical discontinuities due to the refraction of a wavefront. 
385 Key seismic horizons taken from the DOBRE-2 CDP profile (upper panel; Fig. 7) are

386

387

388

389

390

391

392

393

394

395

396

397

398

399

400

401

402

403

404

405

406

407

408

409

410

411

412

413

414

415

416

417

superimposed on the time-converted WARR velocity model (lower panel; Fig. 7). The yellow line corresponds to seismic horizon Ia (top Maykopian), the pinkish line to IIIm (top Mesozoic). The dotted white line represents the base of anything in the seismic image that looks "sedimentary". It corresponds roughly with the bottom of the coloured in parts of the CDP image. According to the WARR velocity model anything that is below the top of the pink layer (i.e., velocity $>\sim 5.8 \mathrm{~km} / \mathrm{s}$ ) likely corresponds to crystalline basement rocks whereas the overlying orange layer (velocity $\sim 5.4-5.7 \mathrm{~km} / \mathrm{s}$ and lying largely below the dotted white line marking the base of sedimentary strata from the CDP image) could be interpreted as representing highly indurated (meta-)sedimentary rocks.

Figure 7 (lower panel) indicates that the structural high below the main Crimea-Caucasus inversion on the southern Kerch Peninsula and Kerch Shelf, where older sedimentary strata, including Mesozoic strata occur at or near the surface, is supported by a deeper crystalline basement high. The same is true of the North Black Sea High-Shatsky Ridge positive structure. On the northern flank of the inversion zone, where the Maykopian succession is thicker than on the southern flank and overlies a Cretaceous succession thicker than elsewhere on the entire profile, the WARR velocities suggest the existence of a substantial preCretaceous sedimentary succession, the base of which lies at a depth greater than $20 \mathrm{~km}$ (Starostenko et al. this volume).

\section{Discussion}

In the northeastern Black Sea the Crimea-Caucasus Inversion Zone is bordered on its southern flank by a basin - the Sorokin Trough, which is in turn bordered by a basement high - the North Black Sea High-Shatsky Ridge, then another depocentre - the EBS, and the another basement high - the Andrusov Ridge. The Sorokin Trough is mainly filled with Maykopian sediments but is structurally complicated by reverse faulting, some faults displaying geometries suggesting that they are inverted extensional structures. To the north of the Crimea-Caucasus Inversion Zone, as seen in the whole DOBRE-2 CDP image, the IndoloKuban Trough is also primarily filled with Maykopian strata, although the Indolo-Kuban Trough is much less structurally complex that the somewhat symmetric Sorokin Trough on the southern side of the inversion zone. The younger (post-Mesozoic) sedimentary complexes are 
418 mostly absent in the inversion zone itself where Mesozoic strata are near the surface,

419 structurally equivalent to the Cretaceous-Jurassic strata that is uplifted and exposed in the

420 Crimea Mountains to the west.

421

422 The WARR velocity model shows that the southern flank of the main inversion zone is

423 underlain by a basement uplift below the Mesozoic complex, indicating a thick-skinned,

424 basement-involved, mode of shortening. Seismic horizon IIIm (top Mesozoic; pinkish line in

425 the lower panel of Figure 7) and the sub-parallel dotted white line at the base of clear

426 sedimentary layering can be taken as representations of vertical displacement of basement

427 during Cenozoic inversion. These show, despite some degree of asymmetry, that the Indolo-

428 Kuban and Sorokin troughs can be considered as marginal troughs formed synchronously and

429 adjacent to a developing central inversion zone as predicted theoretically by Hansen \& Nielsen

430 (2003), who built a numerical model of the compressional shortening of a pre-existing rift

431 basin at the crustal scale. In the Hansen \& Nielsen (2003) model the "marginal troughs" of

432 basin inversion axes (such as clearly expressed, for example, along the inverted Polish Basin;

433 e.g. Dadlez et al. 1995) form as a flexural isostatic response to crustal scale thickening and

434 concomitant density changes caused by the compressional shortening. This is not crustal

435 folding or buckling, which is an anelastic response to loading, nor is it flexural foreland basin

436 subsidence, which is caused by the regional isostatic response to surface loading of thrust

437 sheets. Nevertheless, the formation of these marginal trough basins is intrinsically linked to the

438 tectonic shortening and mountain-building processes that are occurring, as was recognised for

439 the Crimean Mountains and Sorokin Trough by Yudin (2011) and Yudin \& Gerasimov (1992).

440

441 In a more regional context, the Indolo-Kuban Trough continues to the east of the present study

442 area (e.g. Fig. 1) to lie north of the Greater Caucasus Orogen in Russia (cf. Figure 1 in

443 Nikishin et al. [this volume], where it is labelled the West Kuban Basin). In the context of the

444 symmetry and co-genetic implications for the Indolo-Kuban Trough and Sorokin Trough

445 inferred in the present study, the Tuapse Trough, south of the Russian margin of the EBS, can

446 be considered to be the analogous marginal trough counterpart basin on southern flank of the

447 Greater Caucasus Orogen. Thus, on a regional scale, the Sorokin and Tuapse troughs form one

448 single tectonic entity to the south of the Crimea-Caucasus Inversion Zone and related to its

449 formation.

450 
451 The asymmetry of the marginal Sorokin and Indolo-Kuban troughs displayed in the present

452 study area, centred on the southern Kerch Peninsula-Kerch Shelf, is likely related to an

453 initially asymmetric basement structure. There is an older deeper basin inferred by the WARR

454 velocity model to the north of the inversion directly underlying the thick Mesozoic sucession

455 of the southern Indod-Kuban Trough imaged by the CDP profile. This might well represent the

456 deeper expression of the Jurassic Greater Caucasus Basin, which is the primary entity being

457 inverted to form the Greater Cauacasus orogen (e.g. Nikishin et al. 2010). Sheremet et al. (this

458 volume) and Saintot et al. (2006b) both mention geological evidence from Crimea for active

459 extensional tectonics and rapid basement subsidence in the Jurassic contemporaneous with the

460 main rifting phase of the Greater Caucasus Basin in the area of the present Greater Caucasus

461 orogeny (Saintot et al. 2006a). Accordingly, it is plausible that the Greater Caucasus Basin rift

462 basin lies buried between the Crimea Mountains and the Greater Caucasus itself where it is

463 seen in the exposed geology. In this case, then the seismic image suggests that the main

464 structure controlling inversion in the Kerch Peninsula-Kerch Shelf area could be the bounding

465 faults of the southern margin of the Greater Caucasus rift zone.

466

467 The Palaeocene-Eocene strata of the EBS Basin are not fault-bounded (e.g. Fig. 6) but rather

468 onlap the North Black Sea High-Shatsky Ridge on its north flank. The interpretation shown

469 here accordingly implies an absence of extensional/rift tectonics for this basin in the

470 Palaeogene, which had been previously argued (e.g. Finetti et al. 1988; Robinson et al. 1996).

471 The current interpretation, with its thin, albeit poorly constrained Cretaceous layer underlying

472 the Palaeogene depocentre is a conservative interpretation, made as such given the poor

473 imaging below what is confidently identified as seismic horizon IIIm (top Mesozoic). It is

474 noted that Niksihin et al. (this volume) suggest from other, close-by, regional seismic profiles

475 that a substantial, fault-bounded, syn-rift (Black Sea phase of rifting) Cretaceous succession

476 underlies the IV (?) horizon as shown in Figure 6. This is a plausible interpretation that

477 presupposes but does not diagnostically document that the EBS Basin was formed by active

478 rifting in the Cretaceous, more or less contemporaneously with the WBS (e.g. Stephenson \&

479 Schellart 2010). In either case, the Palaeogene succession as seen in Figure 6 may have formed

480 at least in part as a result of post-rift subsidence over a central EBS rift zone (i.e., as inferred

481 by Nikishin et al. this volume) but the lack of the more regional expression more typical of a

482 broader, overlapping thermal sag over a syn-rift axial depocentre suggests that its formation

483 has also been in part controlled by the compressional tectonics that started in the Eocene (or

484 possibly Palaeocene; Sheremet et al. this volume). As such, the North Black Sea High-Shatsky 
485 Ridge would have formed primarily as a compressional structure during this time, not as a

486 flexural bulge (cf. Nikishin et al. this volume) and probably involving inversion of older

487 structures, contemporaneous with that in the main inversion zone to its north and the

488 subsidence of its marginal Sorokin Trough (cf. Stovba et al. 2013). In this regard it is noted

489 that the northward-dipping zone of seismicity recognized by Gobarenko et al. (this volume)

490 projects to beneath the North Black Sea High-Shatsky Ridge strengthening an interpretation in

491 which this positive structure is actively involved in current compressional tectonic processes

492 in the northern eastern Black Sea.

493

494 It is noted that the contrast in interpretations regarding the thickness of the Maykopian

495 succession overlying this area (e.g. the present interpretation [e.g. Fig. 6] and those of Stovba

496 et al. [2013] and Nikishin et al. [this volume]) has significance for inferring the timing of a key

497 compressional deformation event in the Cenozoic. The latter interpretations permits this to be

498 later than the former: more or less synchronous with (Oligocene-Early Miocene) Maykopian

499 deposition rather than terminated prior to the end of the Oligocene.

500

Summary and conclusions

502

503 The age and architecture of the sedimentary successions of the northeastern EBS basin have

504 been documented from reflection seismic profiling acquired in the area and investigated by

505 Ukrgeofizika and other Ukrainian organisations. These include the one-off regional DOBRE-2

506 CDP profile acquired by Ukrgeofizika in 2007. These studies have allowed the sedimentary

507 successions of the area - from the Kerch Peninsula and Kerch Shelf south to the central Black

508 Sea - to be subdivided into a number of tectono-sedimentary complexes and have revealed a

509 series of basement structural highs separating a series of sedimentary depocentres. This

510 regional architecture of the northeastern EBS was then compared to that imaged to the north of

511 the Kerch Peninsula in the Azov Sea from the regional DOBRE-2 CDP as a whole.

512

513 The dominant driver of the present-day architecture of the study area, as indicated by

514 structural and stratigraphic relationships including erosional gaps and hiatuses, folding and

515 reverse faulting, has been the compressional tectonic regime affecting the area during the

516 Cenozoic. Some but not all reverse faults can be seen to be inverted normal faults developed

517 during earlier extensional regimes when the Jurassic Greater Caucasus and Cretaceous Black

518 Sea back-arc basins were formed. 
520 Compressional deformation and shortening is most severe in the Kerch Peninsula-Kerch Shelf

521 area, which can be characterised as the central inversion zone within the study area. It is part

522 of the contiguous Crimea-Caucasus orogenic belt that is more developed in the Crimean

523 Mountains to the west and most developed in the Greater Caucasus Orogeny to the east.

524

525 Some specific conclusions are as follows:

526

527 (1) Cenozoic sediments are as thick as $5 \mathrm{~km}$ in the area of the Subbotina hydrocarbon

528 discovery (part of what is called the Kerch-Taman Trough). The discovery is within an

529 anticlinal structure complicated by thrust faults unconformably overlain by Quaternary-

530 Pliocene deltaic deposits.

531

532

(2) The Sorokin Trough is some 40-50 km wide, covering the major part of Black Sea

continental margin, locates $\sim 50 \mathrm{~km}$ south of the Crimean Peninsula coast and running for $\sim 150$

$534 \mathrm{~km}$ along the coastline. It is filled with Maikopian sediments, predominantly) clays of greater than $5 \mathrm{~km}$ thickness overlain with the Middle Miocene-Quaternary sandy-clay deposits as 536 thick as $3.5-4 \mathrm{~km}$.

537

538 (3) The Sorokin Trough is a marginal trough to the main Crimea-Caucasus Inversion Zone 539 with the Indolo-Kuban Trough beneath the Azov Sea its northern margin counterpart in the 540 present study area.

542 (4) The Shatsky Ridge and the EBS Basin (Palaeocene) are at least in part syn-compressional 543 structures.

\section{Acknowledgements}

547 The authors thank the chief editor of this Special Publication, Marc Sosson (University of Nice

548 Sophia Antipolis, France) and reviewers... RS acknowledges support from the Royal Society

549 of Edinburgh for facilitating the collaboration that has led to the production of this manuscript.

550 This work was partly supported within the statutory activities No. 3841/E-41/S/2015 of the

551 Ministry of Science and Higher Education of Poland. 


\section{References}

ADAMIA, S., GAMKRELIDZE, I. P., ZAKARIADZE, G. S. \& LORDKIPANIDZE, M. V. 1974. Adjara-Trialeti trough and the problem of the Black Sea origin. Geotectonika, 1, 78-94 (in Russian).

AfAnasenkov, A. P., Nikishin, A. M. \& OBUKHOV, A. N. 2007. Eastern Black Sea Basin: Geological Structure and Hydrocarbon Potential. Nauchnui Mir, Moscow (in Russian).

Almendinger, O. A., Mityukov, A. V., Myasoedov, N. K. \& Nikishin, A. M. 2011. Modern erosion and sedimentation processes in the deep-water part of the Tuapse Trough based on the data of 3D seismic survey. Dokl. Earth Sci., 439 (Part 1), 899-901.

Belousov, V. V. \& VolvovsKy, B. S. (eds) 1989. Structure and Evolution of the Earth's Crust and Upper Mantle of the Black Sea. Nauka, Moscow (in Russian).

Dadlez, R., NARKieWicz, M., Stephenson, R.A., Visser, M \& VAN WeES, J-D. 1995. Tectonic evolution of the Polish Trough: modelling implications and significance for central European geology. Tectonophysics, 252, 179-195.

Dercourt, J., GAetani, M. \& VRIELYNCK, B. (eds) 1993. Atlas Tethys, Palaeoenviromental Maps. Gauthier-Villars, Paris.

FInETTI, I., BRICCHI, G., DEL BEN, A., PIPAN, M. \& XUAN, Z. 1988. Geophysical study of the Black Sea. Bolletino di Geofisica Teorica ed Applicata, XXX/117-118, 197-324.

GobAREnKo, V., Yegorova, T. \& STEPHENSON, R., this volume. Local tomography model of the northeast Black Sea: intraplate crustal underthrusting.

GöRÜR, N. 1988. Timing of opening of the Black Sea Basin. Tectonophysics, 147, 247-262.

GOZHYK, P. F., BAGRiY, I. D., VoITSYTSKYI, Z. YA, GLADUn, V. V., MASLUn, N. V., ZnamensKa, T. O., Aks'OM, S. D., Kliushyna, G. V., IVAnik, O. M., KlochKo, V. P., Mel'NichuK, P. M., PALIY, V. M. \& TsioKhA, O. G. 2010. Geological-structural-thermoatmogeochemical substantiation of petroleum presence in the Azov-Black Sea Aquatory. Logos, Kyiv, p. 419 (in Ukrainian).

GOZHYK, P.F., MASLUN, N.V. et al. 2011. Stratigraphic Structure of Cenozoic Deposits of Prekerch Shelf and East Black Sea Basin. AAPG, Search and Discovery Article \#50395.

GRAHAM, R., KAYMAKCI, N. \& HORN, B. W. 2013. The Black Sea: something different? GeO ExPro. October 58-62.

HANSEN, D. L. AND NiELSEN S. B. 2003. Why rifts invert in compression. Tectonophysics, 373, $5-24$.

KhriachtchevsKaia, O., Stovba, S. \& StePhenson, R. 2010. Cretaceous-Neogene tectonic evolution of the northern margin of the Black Sea from seismic reflection data and tectonic subsidence analysis. In: Sosson, M., Kaymakci, N., Stephenson, R., Bergerat, 
612

613

614

615

616

617

618

619

620

621

622

623

624

625

626

627

628

629

630

631

632

633

634

635

636

637

638

639

640

641

642

643

644

645

646

647

648

649

650
KRUGLOV, S. S. \& TsYPKO, A. K (eds.) 1988. Tectonics of Ukraine, Nedra, Moscow (in Russian).

Letouzey, J., Bijou-Duval, B., Dorkel, A., Gonnard, R., KristcheV, K., Montadert, L. \& SungurLU, O. 1977. The Black Sea: a marginal basin; geophysical and geological data. In: Bijou-Duval, B. \& Montadert, L. (eds) International Symposium on the Structural History of the Mediterranean Basins, Editions Technip, Paris, 363-376.

Meijers, M. J. M., Vrouwe, B., Van Hinsbergen, D. J. J., Kuiper, K. F., Wijbrans,, J., DAVis G. R., StePhenSOn, R. A., KAYMAKCI, N., MATENCO, L. \& SAINTOT, A. 2010. Jurassic arc volcanism on Crimea (Ukraine): Implications for the paleo-subduction zone configuration of the Black Sea region. Lithos, 119, 412-426.

Mityukov, A. V., Nikishin, A. M., Almendinger, O. A., Bolotov, S. N., LAVRishcheV, V. A., MyasoedoV, N. K., RuBTsovA, E. V. 2012. A sedimentation model of the Maikop deposits of the Tuapse Basin in the Black Sea according to the results of 2-D and $3-\mathrm{D}$ seismic surveys and field works in the Western Caucasus and Crimea. Moscow $U$. Geol. Bull. 67 (2), 81-92.

Nikishin, A. M., ERShOV, A. V. \& Nikishin, V. A. 2010. Geological history of Western Caucasus and adjacent foredeeps based on analysis of the regional balanced section. Dokl. Earth Sci., 430 (2), 155-157. http://dx.doi.org/10.1134/S1028334X10020017.

Nikishin, A. M., Korotaev, A. M., Ershov, A. V. \& Brunet, M.-F. 2003. The Black Sea basin: tectonic history and Neogene-Quaternary rapid subsidence modelling, Sedimentary Geology, 156, 149-168.

Nikishin, A. M., Khotylev, A. O., Bychkov, A. Yu, Kopaevich, L. F., Petrov, E. I. \& YAPASKURT, V. O. 2013. Cretaceous volcanic belts and the Black Sea Basin history. Moscow U. Geol. Bull., 68 (3), 141-154. http://dx.doi.org/10.3103/S0145875213030058

Nikishin, A. M., Okay, A. I., TÜysüz, O., Demirer, A., Amelin, N \& Petrov, E. 2015a. The Black Sea basins structure and history: New model based on new deep penetration regional seismic data. Part 1: Basins structure and fill. Marine and Petroleum Geology, 59, 638-655.

Nikishin, A.M., OKay, A. I., TÜysüz, O., Demirer, A., WAnnier, M., Amelin, N. \& Petrov, E. 2015b. The Black Sea basins structure and history: New model based new deep penetration regional seismic data. Part 2: Tectonic history and paleogeography. Marine and Petroleum Geology, 59, 656-670.

Nikishin, A. M., Wannier, M., Alekseev, A. S., Almendinger, O. A., Fokin, P. A., Gabdullin, R. R., Khudoley, A. K., Kopaevich, L. F., Mityukov, A. V., Petrov, E. I. $\&$ RubTsova, E. V., this volume. Mesozoic to recent geological history of southern Crimea and the Eastern Black Sea region. 
661

662

663

664

665

666

667

668

669

670

671

672

673

674

675

676

677

678

679

680

681

682

683

684

685

686

687

688

689

690

691

692

693

694

695

696

697

698

699

700

OKAY, A. I., ŞENGÖR, A. M. C. \& GÖRÜR, N. 1994. Kinematic history of the opening of the Black Sea and its effect on the surrounding regions. Geology, 22, 267-270.

PoBEDASH, M. 2006. Forecast of oil zones in the Black Sea based on regional seismic studies and synthesis of information on the geology, geodynamics and petroleum potential of the Azov-Black Sea region. DGP TC "UkrGeofizika”, Kyiv (in Ukrainian).

POBEDASH, M. 2008. Report on regional geophysical surveys along the DOBRE-2 profile (Feodosiya-Starobeshevo). Report of State Geophysical Company "UkrGeofizika”, Kyiv (in Ukrainian).

POPADYUK, I. 2009. CDP regional seismic study within the Ukrainian sector of the Black Sea. Report of the Company "Naukanaftogaz", Kyiv (in Ukrainian).

Popadyuk, I. V., Stovba S. M. \& KhriachtchevskaiA, O. I. 2013. The new geological map of the Crimea Mountains by SPK-Geoservice as a new approach to understanding the Black Sea Region. Abstracts, Darius Programme Workshop, 24-25 June, 2013, Tbilisi, Georgia, 48-50.

RANGin, C., BADER, A. G., PASCAL, G., ECEVItoĞLU, B. \& GorÜR, N. 2002. Deep structure of the Mid Black Sea High (offshore Turkey) imaged by multi-channel seismic survey (BLACKSIS cruise). Mar. Geol., 182, 265-278.

ROBINSON, A.G. \& KERUSOV, E. 1997. Stratigraphic and structural development of the Gulf of Odessa, Ukrainian Black Sea: implications for petroleum explorations. In: Robinson, A.G. (ed) Regional and Petroleum Geology of the Black Sea and Surrounding Region, AAPG Memoir, 68, 369-380.

Robinson, A.G., RUdAT, J.H., BANKS, C.J. \& WiLES, R. L. F. 1996. Petroleum geology of the Black Sea. Marine and Petroleum Geology, 13, 195-223.

SAintot, A., BRUnet, M.-F., YAKOVlev, F., SÉBRIER, M., StePHENSON, R., ERShOv, A., Chalot-Prat, F. \& McCann, T., 2006a. The Mesozoic-Cenozoic tectonic evolution of the Greater Caucasus. In: Gee, D. \& Stephenson, R. (eds) European Lithosphere Dynamics. Geological Society, London, Memoirs, 32, 277-289.

Saintot, A., Stephenson, R., Stovba, S., Brunet, M.-F., Yegorova, T. \& StAROSTENKO, V. 2006b. The evolution of the southern margin of the Eastern Europe (Eastern European and Scythian platforms) from latest Precambrian-Early Palaeozoic to the Early Cretaceous. In: Gee, D. \& Stephenson, R. (eds) European Lithosphere Dynamics. Geological Society, London, Memoirs, 32, 481-505.

SCotT, C. L., Shillington, D. J., Minshul, T. A., EDwards, R. A., Brown, P. J. \& WHITE, N. J., 2009. Wide-angle seismic data reveal extensive overpressures in the Eastern Black Sea Basin. Geophys. J. Int., 178, 1145-1163. http://dx.doi.org/10.1111/j.1365246X.2009.04215.x

Sheremet (KorniyenKo), Ye., Sosson, M., Müller, C., Gintov, O., Murovskaya, A. YEGOROVA, T., this volume. Key problems of stratigraphy in the Eastern Crimea Peninsula: some insights from new dating and structural data. 
Shillington, D. J., White, N., Minshull, T. A., EdWARds, G. R. H., Jones, S., EDWARDS, R. A. \& SCOTT, C. L. 2008. Cenozoic evolution of the eastern Black Sea: A test of depth-dependent stretching models, Earth planet. Sci. Lett., 265, 360-378, doi: 10.1016/j.epsl.2007.10.033.

Shillington, D. J., Scott, C. L., Minshull, T. A., Edwards, R. A., Brown, P. J. \& WHITE, N. 2009. Abrupt transition from magma-starved to magma-rich rifting in the eastern Black Sea. Geology, 37/1, 7-10.

STAROSTENKO et al., this volume. DOBRE-2 WARR profile: the Earth's crust across Crimea between the pre-Azov Massif and the north eastern Black Sea Basin.

Starostenko, V., Buryanov, V., Makarenko, I., Rusakov, O., Stephenson, R., Nikishin, A., Georgiev, G., Gerasimov, M., Dimitriu, R., Legostaeva, O., Pchelarov, V. \& SAVA, C. 2004. Topography of the crust-mantle boundary beneath the Black Sea Basin. Tectonophysics, 381, 211-233.

StarostenKo V.I., KRUPSKIY, B.I. et al. 2011. Fault Tectonics of the NE Black Sea Shelf and Its Relevance Hydrocarbon Potential. AAPG, Search and Discovery Article \#30155.

STEPHENSON, R. \& SCHELlART, W. P. 2010. The Black Sea back-arc basin: insights on its origin from geodynamic models of modern analogues. In: Sosson, M., Kaymakci, N., Stephenson, R., Bergerat, F. \& Starostenko V. (eds) Sedimentary Basin Tectonics from the Black Sea and Caucasus to the Arabian Platform, Geological Society, London, Special Publicatons, 340, 11-21.

StOVBA, S. \& KHRIACHTCHEVSKAIA, O. 2011. Driving and triggering mechanisms of inversion tectonics in the Ukrainian Black Sea. In: 3rd International Symposium on the Geology of the Black Sea Region, 1-10 October 2011, Bucharest, Romania, Abstracts, GeoEcoMar (Suppl), 17, 177-179.

Stovba, S., KhriachtcheVskaia, O. \& PopadyuK, I. 2009. Hydrocarbon-bearing areas in the eastern part of the Ukrainian Black Sea. Leading Edge, 28 (9), 1042-1045

Stovba, S., Khriachtchevskaia, O. \& PopadyuK, I. 2013. Crimea and Ukrainian Eastern Black Sea Basin as an inverted Early Cretaceous rift system. Abstracts, Darius Programme Workshop, 24-25 June, 2013, Tbilisi, Georgia.

TPAO/BP Eastern Black Sea Project Study Group 1997. A promising area in the Eastern Black Sea. Leading Edge, 28 (9), 1001-1004.

Tsiokha, O., SydorenKo, G., Voitsitskiy, Z. \& Pobedash, M. 2008. Regional geophysical research along the DOBRE-2 profile. Report of State Geophysical Company "UkrGeofizika", Kyiv (in Ukrainian).

Tugolesov, D. A., GorshKov, A. S., MeIsner, L. B. et al. 1985. Tectonics of MesozoicCenozoic Successions of the Black Sea Basin. Nedra, Moscow (in Russian). 
Yegorova, T. \& GobarenKo, V. 2010. Structure of the Earth's crust and upper mantle of West- and East Black Sea Basins revealed from geophysical data and their tectonic implications. In: Sosson, M., Kaymakci, N., Stephenson, R., Bergerat, F. \& Starostenko V. (eds) Sedimentary Basin Tectonics from the Black Sea and Caucasus to the Arabian Platform, Geological Society, London, Special Publicatons, 340, 23-42.

Yegorova, T. P., BARANOVA, E. P. \& OMELCHENKO, V. D. 2010. The crustal structure of the Black Sea from reinterpretation of Deep Seismic Sounding data acquired in the 1960s. In: Sosson, M., Kaymakci, N., Stephenson, R., Bergerat, F. \& Starostenko V. (eds) Sedimentary Basin Tectonics from the Black Sea and Caucasus to the Arabian Platform, Geological Society, London, Special Publicatons, 340, 43-56.

YegOROVA, T., GOBARENKO, V. \& YANOVSKAYA, T. 2013. Lithosphere structure of the Black Sea from 3-D gravity analysis and seismic tomography. Geophys. J. Int., 193, 287303.

YUDIN, V.V. \& GERASIMOV, M.YE. 1992. Geodynamic model of the Crimea-Black Sea and adjacent regions. In: Geodynamics of the Crimea-Black Sea Region, Simferopol, 16-23 (in Russian).

YUDIN, V.V. 2011. Geodynamics of Crimea. Simferopol, DAAIPI, 336 p. (in Russian).

Zonenshain, L. P. \& LE PiChON, X. 1986. Deep basins of the Black Sea ans Caspian Sea as remnants of Mesozoic back-arc basins. Tectonophysics, 123, 181-211. 
Figure 1. The study area in the northeastern Black Sea-Crimea (Kerch Peninsula)-Azov Sea: tectonic and structural background (left panel) and locations of seismic lines (55-407, 161-94, 54-94 and DOBRE-2; both panels) and wells (Sinop-1, Subbotina 1, 2, 3 and 403; right panel) mentioned in the text. Blue contour lines (50, 100, 200, 500, 1000, 1500 and $2000 \mathrm{~m}$ ) represent bathymetry (water depths are less than 50 m everywhere in the Azov Sea) and black contour lines represent the structural disposition of horizon IIIm (see text), the top of the Mesozoic succession (contour interval generally 200-300 m, depending on detail). The seismic grids seen in the right-hand panel are those the interpretation of which has contributed to the present study (Western Geophysical 1994 - black lines; Polar Trade Research Associates 2005 are reproduced with geological interpretations in this paper.

Figure 2. Ukrgeofizika regional stratigraphic column for the study area identifying seismic horizons interpreted on seismic profiles seen in Figures 3-7. Not all labelled horizons or uncomformities are discussed in the present text.

Figure 3. Seismic profile 55-407 (located on Figure 1) across the Subbotina oil field, within the Kerch Trough dominated by thrust tectonics and showing wells 1-3 and 403 (Fig. 1). Solid black lines indicate seismo-stratigraphic horizons with labels related to the stratigraphic column in Figure 2. Red lines indicate inferred thrusts.

Figure 4. Seismic profile 161-94 (located on Figure 1) across the Sorokin Trough and North Black Sea High. Solid black lines indicate seismo-stratigraphic horizons with labels related to the stratigraphic column in Figure 2. Red lines indicate inferred thrusts.

Figure 5. Seismic profile 54-94 (located on Figure 1) across the northern termination of the EBS Basin. Solid black lines indicate seismo-stratigraphic horizons with labels related to the stratigraphic column in Figure 2. Red lines indicate inferred thrusts.

Figure 6. Seismic profile DOBRE-2 (northern eastern Black Sea segment) from the Kerch Shelf south to the Andrusov Ridge on the southern flank of the EBS Basin axis.

Solid black lines indicate seismo-stratigraphic horizons with labels related to the stratigraphic column in Figure 2. Red lines indicate inferred faults.

Figure 7. Upper panel: the whole of the DOBRE-2 regional CDP profile, horizontally compressed, showing the seismo-stratigraphic complexes of the Kerch Peninsula and Azov Sea correlatable with those of the northern eastern Black Sea. Solid black lines indicate seismo-stratigraphic horizons with labels related to the stratigraphic column in Figure 2. Red lines indicate inferred faults. Lower panel: DOBRE-2 WARR velocity model over the extent of the DOBRE-2 CDP profile shown in the upper panel with the vertical axis converted to two-way travel-time, with key horizons from the DOBRE-2 CDP profile superimposed (as explained in the text). 
Table 1. Acquisition parameters and basic processing sequence for CDP data within the Black Sea (Ukrainian sector) used in the present study.

\begin{tabular}{|c|c|c|c|}
\hline \multicolumn{4}{|c|}{ ACQUISITION PARAMETERS } \\
\hline Seismic survey & $\begin{array}{l}\text { DOBRE-2 (2007) \& } \\
\text { Titul-407 (2008) }\end{array}$ & $\begin{array}{l}\text { Polar Trade Research } \\
\text { Associates (2005) }\end{array}$ & $\begin{array}{l}\text { Western Geophysical } \\
\text { (1994) }\end{array}$ \\
\hline Ship`s name & Iskatel & Professor Polshkov & Western Challenger \\
\hline Recording system & MSX I/O & MSTS Syntrak 480-16 & TITAN 1000 \\
\hline Recording format & SEG-D & SEG-D & SEG-D \\
\hline Record length (s) & 15 & 15 & 9 \\
\hline Sampling rate (ms) & 2 & 2 & 2 \\
\hline Streamer type & INPUT/OUTPUT & $\begin{array}{l}\text { Syntrak } 480 \text { Digital } \\
\text { Model LDA }\end{array}$ & Streamer \\
\hline $\begin{array}{l}\text { Recorded seismic } \\
\text { channels }\end{array}$ & 240 & 480 & 324 \\
\hline $\begin{array}{l}\text { Length of streamer } \\
\text { (m) }\end{array}$ & 3000 & 6000 & 4050 \\
\hline Group interval (m) & 12.5 & 12.5 & 12.5 \\
\hline Minimal offset (m) & 165 & 120 & 137 \\
\hline Cable depth (m) & 9 & 8 & 9 \\
\hline Seismic source & Sleeve airgun array & Airgun array system & Sleeve airgun array \\
\hline $\begin{array}{l}\text { Total volume (cubic } \\
\text { inches) }\end{array}$ & 1520 & 3800 & 4500 \\
\hline Shot interval (m) & 50 & 50 & 25 \\
\hline Source depth (m) & 6 & 6 & 6 \\
\hline \multicolumn{4}{|c|}{ DATA PROCESSING FLOW } \\
\hline \multicolumn{4}{|c|}{ Reading of the field seismic data in SEG-D format and reformat to ProMAX system } \\
\hline \multicolumn{4}{|c|}{ Geometry definition and create database profile } \\
\hline \multicolumn{4}{|c|}{ Interactive editing bad shots and receivers } \\
\hline \multicolumn{4}{|c|}{ CDP velocity analysis } \\
\hline \multicolumn{4}{|l|}{ Getting stack brute } \\
\hline \multicolumn{4}{|l|}{ Amplitude recovery } \\
\hline \multicolumn{4}{|l|}{ Bandpass filtering } \\
\hline \multicolumn{4}{|c|}{ The weakening of linear wave noise (FK filtering) } \\
\hline \multicolumn{4}{|c|}{ Predictive minimum-phase deconvolution } \\
\hline \multicolumn{4}{|c|}{ Velocity analysis (step each $100 \mathrm{CDP}$ ) } \\
\hline \multicolumn{4}{|c|}{ Suppression of multiples (Radon filtering) } \\
\hline \multicolumn{4}{|c|}{ Velocity analysis (each 50 CDP step). } \\
\hline \multicolumn{4}{|c|}{ Additional bottom and top muting } \\
\hline \multicolumn{4}{|l|}{ DMO } \\
\hline \multicolumn{4}{|c|}{ Velocity Analysis after DMO } \\
\hline \multicolumn{4}{|c|}{ Final stacking } \\
\hline \multicolumn{4}{|c|}{ Minimum-phase deconvolution } \\
\hline \multicolumn{4}{|l|}{ FX deconvolution } \\
\hline \multicolumn{4}{|c|}{ Kirchhoff post-stack migration } \\
\hline Variable in time ban & ss filtering & & \\
\hline
\end{tabular}




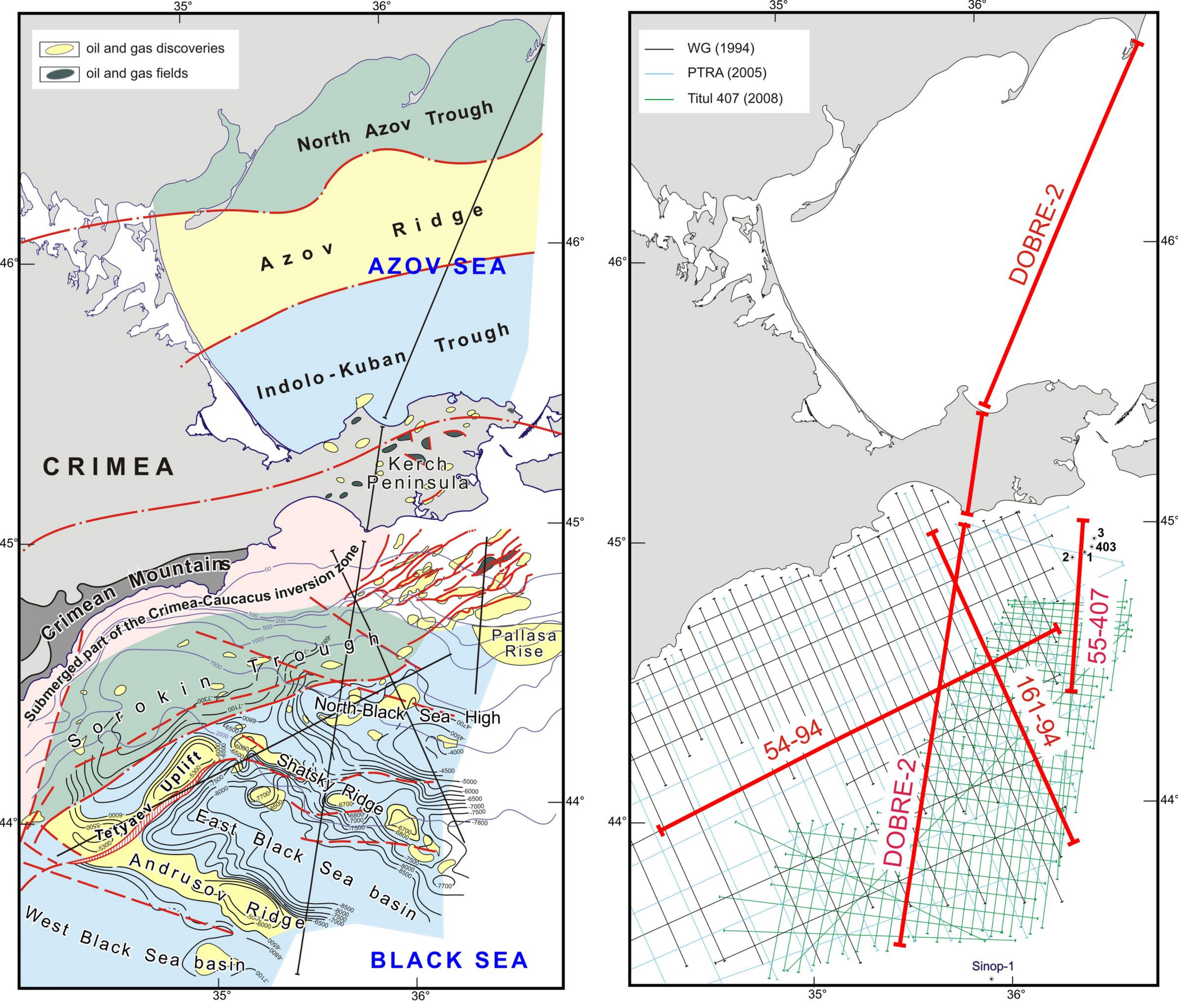

Fig. 1 


\begin{tabular}{|c|c|c|c|c|c|}
\hline 就 & $\begin{array}{l}\text { 음 } \\
.0 \\
0 \\
0\end{array}$ & $\begin{array}{l}\text { 등 } \\
\text { 요 }\end{array}$ & Stage & $\begin{array}{l}\text { Uncon- } \\
\text { formity }\end{array}$ & $\begin{array}{l}\text { Seismic } \\
\text { horizon }\end{array}$ \\
\hline \multirow{5}{*}{0} & \multirow{7}{*}{$\begin{array}{l}0 \\
\text { c } \\
0 \\
0 \\
0 \\
0 \\
z\end{array}$} & \multirow{2}{*}{$\begin{array}{l}\text { 을 } \\
\text { 음 }\end{array}$} & Piacenzian & \multirow{6}{*}{$\sim$ Attic } & \multirow{6}{*}{$\begin{array}{l}\longleftarrow \text { Ip } \\
\text { I Is }\end{array}$} \\
\hline & & & Zanclean & & \\
\hline & & \multirow{6}{*}{ 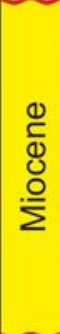 } & Messinian & & \\
\hline & & & Tortonian & & \\
\hline & & & Serravallian & & \\
\hline 0 & & & Langhian & & \\
\hline & & & Burdigalian & \multirow{4}{*}{$\sim$ Sava $\sim$} & 51 \\
\hline$N$ & & & Aquitanian & & \multirow[t]{3}{*}{$\leftarrow 1$} \\
\hline \multirow{3}{*}{0} & \multirow{6}{*}{$\begin{array}{l}0 \\
c \\
0 \\
0 \\
0 \\
0 \\
\text { ఠ }\end{array}$} & \multirow{2}{*}{ 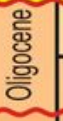 } & Chattian & & \\
\hline & & & Rupelian $\Sigma$ & & \\
\hline & & \multirow{4}{*}{ 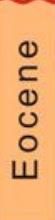 } & Priabonian & & \multirow{3}{*}{$\begin{array}{l}\longleftarrow \text { IIa } \\
\longleftarrow \text { IIb }\end{array}$} \\
\hline \multirow{2}{*}{$z$} & & & Bartonian & & \\
\hline & & & Lutetian & & \\
\hline ш & & & Ypresian & & \multirow{4}{*}{$\leftarrow$ III } \\
\hline \multirow{3}{*}{0} & $\bar{\sigma}$ & \multirow{3}{*}{ 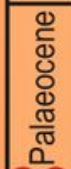 } & Thanetian & & \\
\hline & 0 & & Selandian & & \\
\hline & & & Danian & \multirow{20}{*}{ Laramide } & \\
\hline \multirow{6}{*}{0} & \multirow{12}{*}{$\begin{array}{l}0 \\
J \\
0 \\
0 \\
0 \\
0 \\
\pm \\
0 \\
\vdots \\
0\end{array}$} & \multirow{6}{*}{$\begin{array}{l}\vdots \\
0 \\
a \\
a \\
0\end{array}$} & Maastrichtian & & \multirow{19}{*}{$\longleftarrow$ IIIm } \\
\hline & & & Campanian & & \\
\hline & & & Santonian & & \\
\hline & & & Coniacian & & \\
\hline & & & Turonian & & \\
\hline & & & Cenomanian & & \\
\hline \multirow[t]{2}{*}{0} & & \multirow{6}{*}{$\begin{array}{l}2 \\
0 \\
3 \\
0 \\
-1\end{array}$} & Albian & & \\
\hline & & & Aptian & & \\
\hline$N$ & & & Barremian & & \\
\hline \multirow{3}{*}{0} & & & Hautervian & & \\
\hline & & & Valanginian & & \\
\hline & & & Berriasian & & \\
\hline (0) & \multirow{7}{*}{ 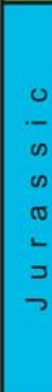 } & \multirow{3}{*}{$\begin{array}{l}\vdots \\
0 \\
0 \\
0 \\
2\end{array}$} & Tithonian & & \\
\hline ш & & & Kimmeridgian & & \\
\hline & & & Oxfordian & & \\
\hline$\Sigma$ & & & Callovian & & \\
\hline & & $\frac{0}{0}$ & Bathonian & & \\
\hline & & $\frac{0}{\Sigma}$ & Bajocian & & \\
\hline & & & Aalenian & & \\
\hline
\end{tabular}


SEISMIC LINE 55-407

\section{WITH GEOLOGICAL INTERPRETATION}

\section{NW} $62 \mathrm{~km}$

SE

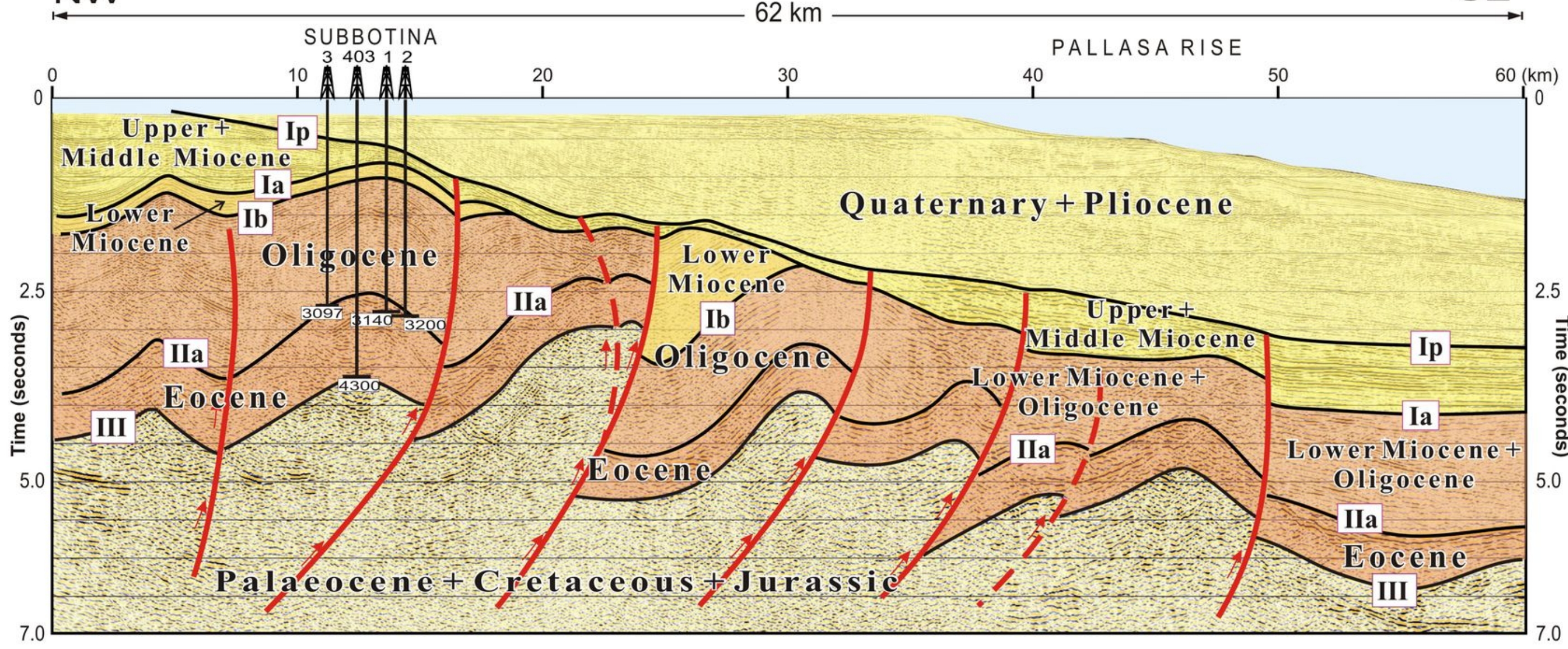

Fig. 3 


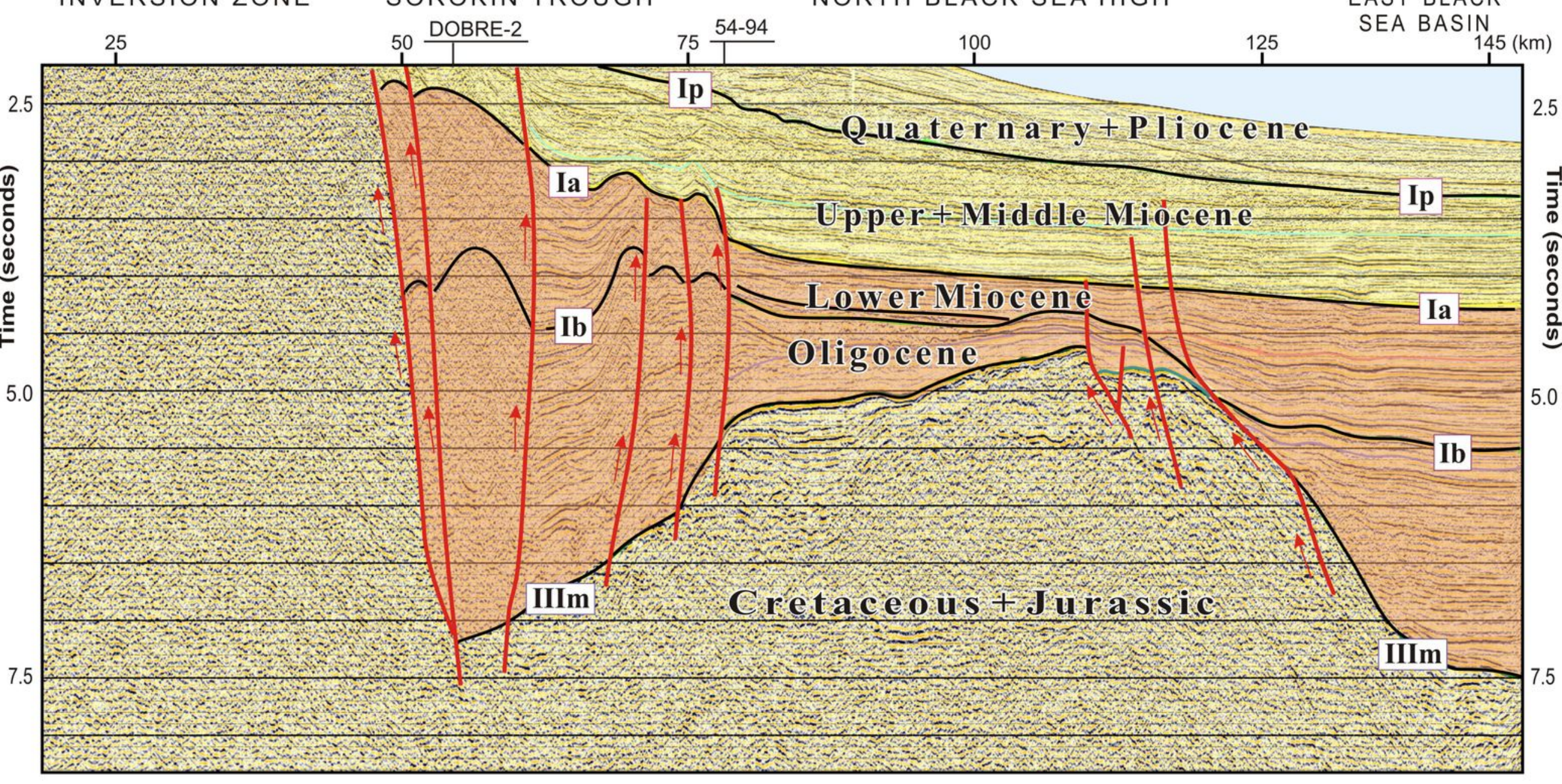

Fig. 4 


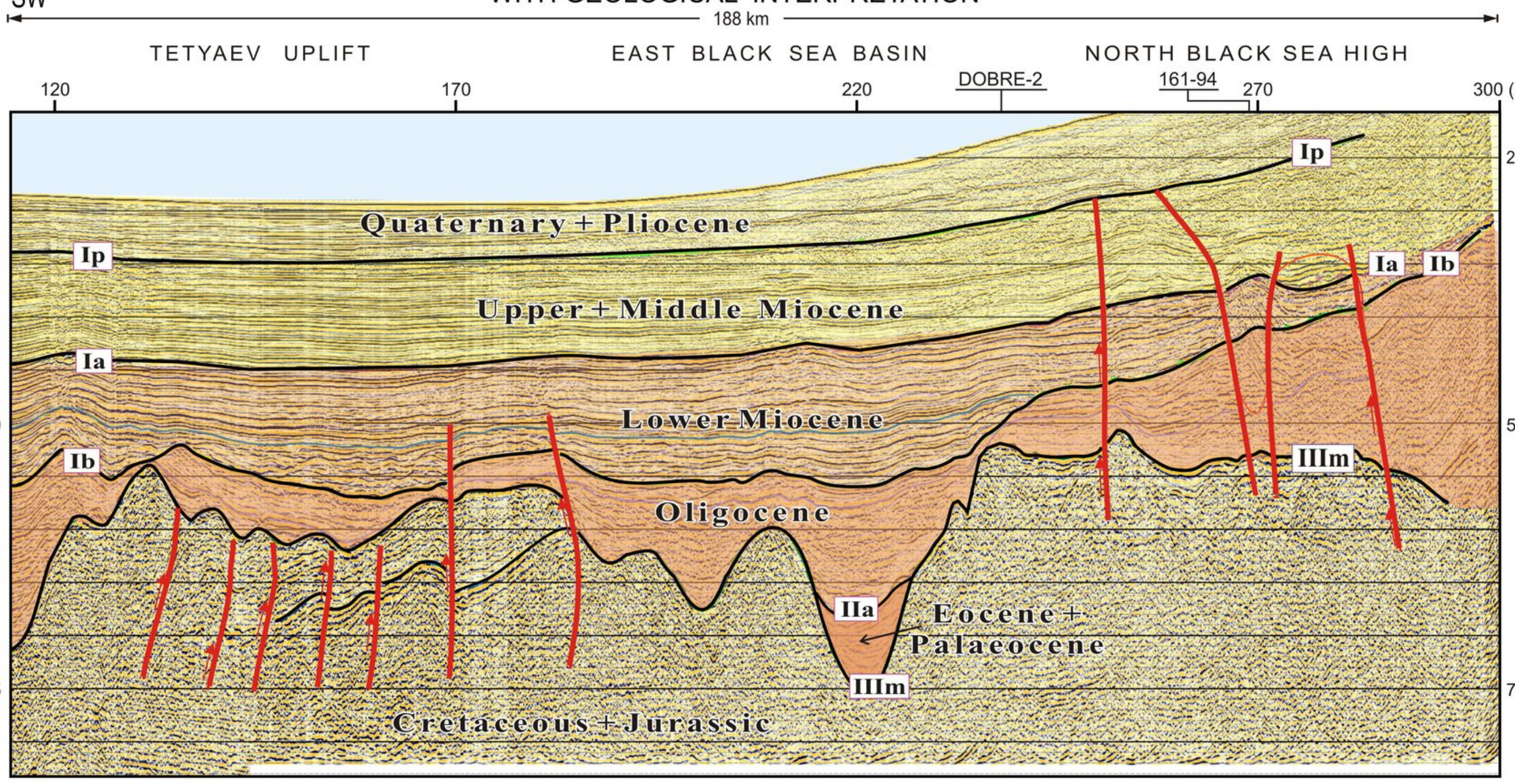

Fig. 5 
